\title{
T-Cell Large Granular Lymphocyte
}

National Cancer Institute

\section{Source}

National Cancer Institute. T-Cell Large Granular Lymphocyte. NCI Thesaurus. Code C38673.

A thymus-dependent white blood cell that has been activated by contact with antigen and has enlarged by macromolecular synthesis with presence of large granules visible by light microscopy. 